\title{
Makna Simbolik Musik Daak Maraaq dan Daak Hudoq dalam Upacara Hudoq Bahau di Samarinda Kalimantan Timur
}

\author{
Asril Gunawan ${ }^{1}$ \\ Program Studi Etnomusikologi, Fakultas Ilmu Budaya, Universitas Mulawarman, \\ Kalimantan Timur, Indonesia
}

\begin{abstract}
The Symbolical Meaning of Daak Maraaq Music and Daak Hudoq of Hudoq Bahau Ritual in Samarinda, East Borneo. The ritual of Hudoq is an annual cultural practice performed by Dayak Bahau people in Samarinda. This ritual's performance consists of some phases in which every stage represents the symbolical meaning closely related to the ceremony's value. Those phases are (1) Lemivaa Lalii; (2) Hudoq Taharii; (3) Lemivaa Tasam; (4) Hudoq Kawit; and (5) Hudoq Pakoq. Daak Maraaq and Daak Hudoq music and Hudoq dance are performed during the ritual. Daak Maraaq and Daak Hudoq are two different kinds of music; both have different styles of performance, stage of implementation, and music style. Due to its complexity, it becomes especially important to analyze the role of the symbolical meaning of music performed in the ritual of Hudoq. It is a qualitative research within an ethnomusicological approach-music within the cultural perspective-which is done through a descriptive-analytical method. The theoretical approach used for this case study is symbolic interpretation and music (transcription) analyses. The theoretical approaches used for this case study are symbolic interpretation and music (transcription) analyses. The research objective, apart from analyzing the symbolic meaning of Daak Maraaq and Daak Hudoq music, is expected to provide information on the vehicle for studying music from an ethnomusicological perspective accompanied by other relevant sciences. According to the data collected, the ritual of Hudoq has an essential role in performing the symbolical meaning of the identical value of practice, social, and existential purpose for the lives of Dayak Bahau people in Samarinda city, East Borneo.
\end{abstract}

Keywords: symbolical meaning; Daak Maraaq; Daak Hudoq; Hudoq ritual

\begin{abstract}
ABSTRAK
Upacara Hudoq adalah peristiwa kebudayaan yang setiap tahunnya diselenggarakan oleh masyarakat Dayak Bahau di kota Samarinda. Pelaksanaan upacara Hudoq terdiri dari beberapa tahapan, dimana setiap prosesinya merepresentasikan makna simbolik yang syarat akan nilai ritualnya. Tahapan upacara Hudoq di Samarinda meliputi: (1) Lemivaa Lalii; (2) Hudoq Taharii; (3) Lemivaa Tasam; (4) Hudoq Kawit, dan (5) Hudoq Pakoq. Prosesi upacara Hudoq juga melibatkan kesenian yang meliputi; musik (Daak Maraaq dan Daak Hudoq) dan tarian (tarian Hudoq). Selanjutnya, musik Daak Maraaq dan Daak Hudoq adalah dua bentuk musik yang berbeda baik secara bentuk penyajian, tempat pertunjukan dan karateristik musikalnya. Melihat prosesi upacara Hudoq yang sangat kompleks, maka penting untuk melihat bagaimana peran makna simbolik musik dalam prosesi ritual upacara Hudoq. Penelitian ini tergolong penelitian kualitatif dengan pendekatan etnomusikologis yakni musik dalam perpektif budayanya melalui metode deskriptif analisis. Adapun teori yang dianggap mewakili dalam bahasan ini adalah penafsiran simbol dan transkrip musik. Tujuan penelitian, selain untuk menganalisis makna simbolik musik Daak Maraaq dan Daak Hudoq, penelitian diharapkan menjadi informasi terhadap wahana kajian musik dalam perspektif etnomusikologis disertai dengan ilmu lainnya yang dianggap relevan. Berdasarkan hasil penelitian menunjukkan upacara Hudoq memiliki peranan penting dalam memainkan peran simbolik terhadap sejumlah nilai-nilai identitas, ritual, sosial dan eksistensi bagi kehidupan masyarakat Dayak Bahau di kota Samarinda, Kalimantan Timur.
\end{abstract}

Kata kunci: makna simbolik; Daak Maraaq; Daak Hudoq; upacara Hudoq

$1 \quad$ Alamat korespondensi: Prodi Etnomusikologi Fakultas Imu Budaya Universitas Mulawarman, Jalan Pulau Flores No. 1 Samarinda Kalimantan Timur. E-mail: gunawanasril5@gmail.com; HP.: 081227062609. 


\section{Pendahuluan}

Kesenian dan kepercayaan (religi) merupakan dua substansi yang saling terkait dalam pencapaian kualitas sakral, sekaligus representasi makna simbolik atas serangkaian aktivitas manusia. Kesenian tradisi musik dan tari pada upacara ritual, merupakan peristiwa budaya yang praktiknya sering dijumpai dalam kehidupan masyarakat tradisi. Peristiwa kesenian ini selanjutnya, diartikulasikan sebagai pemahaman terhadap proses diseminasi kebudayaan lokal. Proses diseminasi dalam fungsinya disesuaikan dengan kebutuhan pendukungnya, musik untuk hiburan atau sebagai ritual. Musik untuk hiburan, dipersepsikan sebagai karya seni yang melahirkan nuansa estetis bagi penikmatnya. Kemudian musik untuk ritual, adalah suatu ranah majemuk, karena ritus dapat diamati sebagai sintetis dari suatu realitas yang bermakna: simbolik dan sosial; individual dan kolektif; serta ritus lazimnya mengutamakan dan mengendalikan tahap simbolik, dari beragam kesenjangan dimasyarakat (Eriksen, 2009).

Kesenian sebagai hiburan ataupun ritual penerapannya perlu disesuaikan pada konteksnya. Secara substansi, kesenian bukan persoalan tontonan atau estetika semata, ia adalah bentuk perwujudan terhadap pertunjukan budaya yang mengisyaratkan arti identitas dan kekhasan bagi suatu etnik (masyarakat). Identitas terjadi melalui norma rakyat yang secara intens selalu menciptakan dan melaksanakan rencana aktivitas seni budaya (Irhandayaningsih, 2018).

Indonesia dikenal kaya akan keberagaman budaya etniknya, termasuk kesenian yang secara utuh memiliki muatan nilai-nilai dan pemaknaan simbolik. Keutuhan tersebut tercermin melalui simbol yang merepresentasikan arti sakral, kemudian manusia menangkap makna sebagai simbol (perlambang) sakral, dalam hubungannya musik dengan konteks upacaranya (Pratiwinindya et al., 2017). Adapun pemaknaan simbolik dari kesenian tradisi salahsatunya terdapat pada musik Daak Maraaq. Musik Daak Maraaq dalam konteks kebudayaan, sebagai sarana untuk menciptakan realitas simbolik dengan berdasarkan kesepakatan bersama antara kelompok atau individu.
Sajian musik Daak Maraaq menunjukan identitas bagi pemilik masyarakat Dayak Bahau. Musik Daak Maraaq yang dihadirkan dalam upacara ritual Hudoq perlakuannya sangat berbeda dengan musik yang bersifat hiburan. Sebagai perilaku simbolik, ritual memiliki standarisasi sosial, karena tindakan ritual memiliki kualitas formalnya sehingga terstruktur dengan makna simbolik (Heriyawati, 2016). Berdasarkan perilaku simbolik, musik Daak Maraaq tergolong ke dalam musik ritual dengan berdasarkan pertimbangan waktu dan tempat kejadiannya.

Upacara Hudoq hingga kini keberadaannya masih disakralkan oleh masyarakat Bahau. Setiap tahunnya upacara Hudoq diperingati dan kompleks karena melibatkan banyak unsur yang meliputi; hubungan sosial, religi, dan kesenian. Hubungan sosial diartikan sebagai perilaku yang terintegrasi, dan pengertian religi diartikan sebagai fenomena kultural. Hubungan sosial melalui peristiwa kesenian dan upacara, menjadikan keakraban masyarakat Dayak Bahau menjadi lebih dinamis dan terpelihara dengan baik.

Kesenian Dayak Bahau yakni musik dan tari sebagai fenomena kultural tidak terpisahkan dalam upacara ritual Hudoq. Upacara ritual Hudoq dan kesenian melebur sebagai suatu domain yang disebut sebagai religi. Persepsi religi mempunyai ragam unsur misalnya keyakinan, ritus, upacara, perbuatan dan pola sikap, dan alam pemikiran, perasaan para pengikutnya (Humaeni, 2015). Unsur ritus (ritual) yang ditandai dengan upacara Hudoq, didalamnya terdapat; ragam dari ritual, perbuatan dan pola tingkah laku melalui tarian Hudoq yang disertai musik. Tarian Hudoq tidak lain adalah bagian dari prosesi upacara adat suku dayak yang dilaksanakan saat masyarakat membuka lahan untuk bercocok tanam (Yanti, 2019).

Upacara Hudoq yang dilaksanakan secara kolektif selalu mengutamakan prinsip bergotong royong dan persiapannya sangatlah kompleks. Dikatakan kompleks, karena terdiri dari beberapa tahapan dan kelengkapan upacara yang meliputi; sesaji, waktu pelaksanaan, pelaku upacara (Dayung, penari Hudoq, pemusik), hingga tahapan prosesi upacara. Adapun tahapan upacara Hudoq meliputi; prosesi Lemivaa Lalii, Hudoq Taharii, Lemivaa 
Tasam, Hudoq Kawit dan Hudoq Pakoq. Pembahasan dari tahapan upacara Hudoq tersebut, akan dibatasi dan difokuskan pada prosesi Lemivaa Lalii' dan Hudoq Taharii'. Tujuan pembatasan adalah untuk melihat sejauhmana relevansi keterlibatan makna simbolik musik Daak Maraaq dan Daak Hudoq dalam upacara Hudoq. Bentuk musik Daak Maraaq dan Daak Hudoq masing-masing memiliki peranan simbolik yang ditempatkan dalam prosesi yang berbeda. Secara musikal kedua bentuk musiknya memiliki kesan auditif yang mampu menghadirkan makna simbolik dalam setiap pertunjukannya.

Secara garis besar musik dapat dipahami sebagai ekspresi manusia yang diungkapkan lewat medium suara atau bunyi. Musik juga mengandung unsur irama dan struktur waktu. Pertunjukan musik ini lebih dominan dalam pengertian seni auditif, atau bagi penikmat musik lebih kepada rasa tangkapan atau persepsi pendengaran (Indrawan et al., 2018). Persepsi pendengaran jika mengacu pada konsteksnya, pertunjukan musik Daak Maraaq dan Daak Hudoq adalah seni auditif yang memiliki peranan makna simbolik. Penyajian musik Daak Maraaq dan Daak Hudoq meskipun berbeda, namun aspek musikalnya memiliki pemaknaan simbolik atas nilai ritual dan sakral. Dikatakan sakral karena musikal, Daak Maraaq dan Daak Hudoq memiliki pola ritme yang tidak boleh dirubah atau dikreasikan. Hal itu tidak lepas dengan teks dan konteks penggunaannya, musik untuk upacara ritual Hudoq.

Pelaksanaan upacara Hudoq dalam tradisi masyarakat Dayak Bahau umumnya dipimpin oleh seorang Dayung dari kaum perempuan. Dipercaya sebagai seorang Dayung dalam upacara jika ia memiliki peran status sosial dimasyarakat. Status sosial Dayung dapat ditentukan dengan berdasarkan keturunan bangsawan yakni Hipui. Seorang Dayung dianggap memiliki kemampuan istimewa, yaitu dapat berkomunikasi dengan roh atau dewa (Yanti, 2019). Saat prosesi berlangsung Dayung tidaklah sendirian, melainkan ia tetap didampingi oleh dua sampai tiga orang Dayung perempuan. Adapun peran Dayung diantaranya mempimpin jalannya prosesi upacara yang diawali dengan ritual Lemivaa Lalii. Prosesi Lemivaa Lalii', secara simbolik adalah pembersihan atau pemberkatan dengan tujuan semua peserta yang terlibat dalam keadaan hati yang suci dan terjaga. Selama prosesi Lemivaa Lalii', alunan musik Daak Maraaq tetap turut dimainkan secara konsisten. Musik disini menjadi sarana untuk memudahkan Dayung dapat lebih khusyuk saat prosesi ritual. Adapun prosesi ritual ditandai ketika Dayung sedang membacakan doa suci disertai alunan musik Daak Maraaq. Suasana alunan musikal dengan irama konsisten menjadikan suasana upacara dan peserta larut dalam suasana sakral.

Instrumen musik Daak Maraaq adalah jenis instrumen yang disakralkan oleh masyarakat Bahau. Musik Daak Maraaq umumnya terdiri dari instrumen gong dan Mebang. Ke-dua jenis instrumen terbuat dari bahan perunggu atau besi dan secara bentuk ada yang berpencon dan tidak berpencon. Instrumen berpencon, termasuk dalam jenis instrumen gong, sedangkan yang tidak berpencon masuk dalam jenis instrumen Mebang. Melihat bentuk, peran dan fungsinya begitu penting, maka keberadaannya patut untuk dijaga dan dilestarikan. Dijelaskan juga bahwa, melihat kesamaan dan perbedaan jenis musik, baik pada instrumen, fungsi, maupun bentuk pertunjukannya, menunjukan bahwa kekayaan budaya musik tradisi sebagai unsur keragaman budaya Nusantara sangat perlu untuk dilestarikan, diteliti dan dikaji lebih serius (Haryanto, 2015).

Alunan sakral musikal Daak Maraaq dapat meningkatkan konsentrasi Dayung saat dilakukan Maraaq (pembacaan doa). Disisi lain, suara alunan musikal Daak Maraaq dipercayai dapat membantu Dayung agar terhindar dari suara-suara yang dianggap tidak baik. Musikal Daak Maraaq dalam konteks simboliknya, terkait erat dengan konteks mitos. Relasi mitos, dianggap relevan dengan musik dijadikan sarana untuk menghindari suara-suara yang dianggap pantang didengar oleh Dayung selama prosesi berlangsung. Artinya, mitos disini telah menguatkan arti pentingnya keberadaan musik Daak Maraaq dalam setiap upacara Hudoq. Tujuannya untuk mengendalikan tindakan dan perilaku dengan disesuaikan pada budaya dan moral masyarakat setempat (Humaeni, 2013).

Karakteristik pola ritmis musik Daak Maraaq yang terdiri dari intrumen gong dan 
Mebang membentuk interlocking figuration (saling mengikat). Rangkaian irama ritmis meski terkesan monoton, namun kedengarannya tetap harmonis dan bernuansa sakral. Keharmonisan rasa musikalitas tidak terpisahkan juga pada irama musik yang dihasilkan dan peran pemain (Gunawan, 2017). Adapun pelaku/pemain musik tidak berarti hanya orang tertentu saja, namun boleh juga dimainkan oleh orang lain dengan catatan telah memahami pola irama musik Daak Maraaq.

Terkait uraian di atas, maka sebelumnya akan dipaparkan terlebih dahulu definisi musik Daak Maraaq dan musik Daak Hudoq. Definisi musik Daak Maraaq dapat dijelaskan ke dalam dua pengertian yang berbeda, secara terminologi dan harafiah. Secara terminologi, musik Daak Maraaq berasal dari dua suku kata, Daak dan Maraaq. Daak adalah musik atau tabuhan sedangkan Maraaq adalah ungkapan atau doa. Pengertian secara harafiah, musik Daak Maraaq adalah musik yang dimainkan dengan menggunakan instrumen gong dan Mebang saat Dayung membacakan doa ritual. Musik Daak Maraaq yang terkesan monoton, dianggap mampu merepresentasikan makna simbolik akan nilai spiritualitas masyarakat Dayak Bahau. Hal ini sejalan dengan budaya masyarakat Bahau, dimana musik melingkupi dunia spiritual dan transendental. Sifat transendental dimaksudkan insan akan semakin terbuka, bahwa pada diri insan masih ada ruang, dan dorongan, dan terdapat pengetahuan buat diisi dan menciptakan sesuatu (Hardjana, 2005). Artinya spiritual dan transendental akan terbentuk dan mengenal konsep diri dan lingkungannya ketika masyarakat Dayak Bahau tidak terpisahkan pada lingkungan dan alamnya.

Selanjutnya, definisi musik Daak Hudoq adalah musik yang terdiri dari instrumen Tuvung (gendang), gong dan Mebang. Pendefinisian tersebut diamati berdasarkan peran musik dalam prosesi Hudoq Taharii. Pada umumnya musik Daak Hudoq digunakan untuk mengiringi Ngarang Hudoq (tarian Hudoq) dilapangan terbuka. Dengan demikian dapat dikatakan musik Daak Hudoq sangat berbeda dengan musik Daak Maraaq namun keduanya memiliki peran sebagai arena simbolik. Musik Daak Hudoq dalam upacara
Hudoq Taharii secara simbolik sebagai media spiritual dan transendental. Pada prinsipnya, pertunjukan musik Daak Hudoq menjadi penting dalam mengaktualisasikan makna simbolik saat prosesi Hudoq Taharii. Pertunjukan musik Daak Hudoq sebagai representasi spiritual yang mengandung aspek simbolik dan ter-ekpresikan secara kolektif. Dengan aspek simbolik itu, peran dalam menciptakan tanda-tanda diwujudkan melalui upacara untuk memberikan pesan spiritual transendentalnya (Hendriyana, 2009). Fase selanjutnya, transendental yang 'rasa' ini akan diartikulasikan melalui wujud simbol-simbol akar budayanya. Hal tersebut merupakan awal mula terjadinya ritual, upacara religi dan simbol-simbol religi (Muthohar \& Masykhur, 2020).

Mengingat pentingnya keberadaaan musik Daak Maraaq dan Daak Hudoq, maka disayangkan jika tidak terperhatikan, terlebih pengaruh perkembangan zaman. Disini diperlukan kesadaran bagaimana menempatkan praktik kesenian dengan tidak mengabaikan nilai-nilai lokalitasnya. Artinya, ada kekhawatiran praktik kesenian musik Daak Maraaq dan Daak Hudoq perlahan-lahan akan punah atau tidak bertahan lama, karena kuatnya pengaruh perkembangan zaman. Dampak perkembangan zaman akan begitu cepat dapat merubah perilaku masyarakat. Strategi pelestarian bagaimanapun menjadi skala proritas agar praktik kesenian tradisi tetap berkelanjutan dikalangan generasi penerusnya. Tujuannya adalah mendukung kesenian tradisi sebagai penguatan makna simbolik, senantiasa dapat terpelihara dan terjaga keberlangsungannya. Adapun bentuk penguatan makna simbolik musik dalam upacara Hudoq, nantinya akan dijelaskan pada bab pembahasan selanjutnya.

Seiring perkembangannya, perhatian dan eksistensi kesenian tradisi yakni; musik, tari dan upacara ritual sangat perlu mendapatkan apresiasi dan dukungan dari seluruh lapisan masyarakat, budayawan, peneliti, akademisi seni, serta instansi pemerintahan. Tujuan apresiasi, sebagai bentuk dan upaya menciptakan lingkup sosial yang terorganisir, menjadi ruang kontemplatif (kesadaran) bagi pelestarian seni tradisi yang berkelanjutan. Secara substansi, bentuk dukungan pelestarian di atas, 
dilakukan dengan mengarah pada riset (kajian) dengan berbagai pendekatan ilmu humaniora dan displin ilmu-ilmu lainnya yang relevan (transdisiplin dan multi-disiplin). Salah satu bentuk dukungan dalam hal ini adalah dengan pendekatan kajian etnomusikologis.

Kajian etnomusikologis dianggap penting untuk melihat persoalan keberlanjutan praktik musik tradisi, agar dapat terdokumentasikan dengan baik. Dengan demikian, musik dalam konteks budaya di Kalimantan Timur pun perlu digali secara mendalam. Cakupannya seperti pada bentuk kesenian, konsep musikal, fenomena musik, pemaknaan simbol musik, persebaran musik, fungsi, sosial dan kontinuitas musik dan lain sebagainya. Adapun literasi terhadap kajian atau penelitian tentang musik Daak Maraaq dan Daak Hudoq sebagai arena simbolik hingga saat masih sangat jarang ditemukan.

Berdasarkan latar belakang di atas, maka makna simbolik musik dalam upacara Hudoq di Samarinda, Kalimantan Timur dianggap penting untuk diungkap dan dijelaskan dalam penelitian ini.

\section{Metode Penelitian}

Penelitian ini termasuk dalam penelitian kualitatif dengan menggunakan metode deskriptif dan analisis. Pengumpulan data riset dilakukan dengan teknik wawancara ke beberapa informan yang dianggap mengetahui secara langsung objek yang diteliti termasuk, pelaku musik dan Dayung. Penulis juga melakukan observasi aktif sejak beberapa tahun terakhir sebagai proses pengamatan, dan tambahan informasi data lapangan. Penelitian dilakukan dengan studi lapangan, untuk kelengkapan data berupa rekaman audio dan dokumentasi foto. Proses pengumpulan data, juga disertai dengan tinjauan pustaka khususnya penulisan yang membahas tentang upacara $H u d o q$ maupun tarian Hudoq. Disebutkan bahwa, tugas pokok seorang etnomusikolog adalah mengamati, mencari data, merancang perangkat analisis musik sasarannya, mencari pengetahuan dan teori tentang musik tersebut berdasarkan kenyataan di lapangan (Santosa, Aton Rustandi Mulyana, 2007).
Selanjutnya data di lapangan dievaluasi meliputi; (1) pemilihan data hasil trans-kripsi; (3) wawancara; dan (3) hasil rekaman audio. Data yang diperoleh dari hasil pengamatan dijadikan data utama untuk dianalisis. Tahap pencatatan, dilakukan dengan mencatat semua data yang masuk baik dari studi pustaka, observasi, maupun wawancara. Selanjutnya disusun dan diklarifikasi berdasarkan permasalahan masing-masing. Metode deskriptif analisis penting untuk menguraikan sistematika penelitian lapangan, dari pola yang simpel hingga pola yang multi-kompleks, sehingga tujuan menjadi tepat sasaran. Deskriptif terkait pemaparan makna simbolik musik dalam upacara Hudoq yang dilaksanakan setahun sekali oleh masyarakat Dayak Bahau di Samarinda Kalimantan Timur. Kemudian data analisis dilakukan dengan pendekatan secara etnomusikologis. Pendekatan etnomusikologis, bertujuan untuk menganalisis musikal Daak Maraaq dan Daak Hudoq dengan menggunakan teknik transkripsi musik (notasi musik) berdasarkan rekaman audio lapangan. Disamping itu, analisis juga dilakukan berdasarkan relasi makna simbolik dan kompleksitasnya lainnya.

\section{Hasil dan Pembahasan}

\section{Upacara Hudoq: Arena Simbolik}

Masyarakat Dayak Bahau di Samarinda, masih memegang teguh adat istiadat dan nilainilai tradisinya melalui upacara Hudoq. Sebelum memasuki prosesi Hudoq, masyarakat terlebih dahulu melakukan prosesi yang diawali dengan kegiatan Ngurang dan Menughal. Ngurang adalah kegiatan memasak Lemang (nasi dalam bambu) yang akan dikonsumsi sebelum Menughal (menanam padi) dan setelah Menughal. Kegiatan Menughal dilaksanakan dengan kesepakatan oleh ketua adat. Namun terkait waktu pelaksanaan, berdasarkan kondisi geografis antara daerah Mahulu (pedalaman) dan kota Samarinda itu berbeda. Upacara Hudoq di Samarinda biasanya dilaksanakan pada bulan November setelah melakukan Menughal.

Berdasarkan pengamatan di lapangan, upacara ritual Hudoq dilaksanakan di dua tempat yang 
berbeda. Tempat upacara merupakan bagian dari arena simbolik. Adapun ke-dua tempat prosesi sebagai arena simbolik dilaksanakan dirumah Dayung dan di lapangan terbuka. Prosesi dirumah meliputi; Lemivaa Lalii dan Lemivaa Tassam kemudian dilapangan meliputi; prosesi Hudoq Taharii, Hudoq Kawit dan Hudoq Pakoq.

Prosesi Lemivaa Lalii, diawali dengan Temiva (pensucian) kepada peserta upacara agar nantinya tidak mempunyai beban rohani karena telah disucikan batinnya. Setelah dilakukan prosesi Lemivaa Lalii' kemudian dilanjutkan dengan prosesi Hudoq Taharii' yang ditempatkan dilapangan terbuka. Setelah itu, dilanjutkan dengan prosesi Lemivaa Tasam yang juga memiliki persamaan dengan prosesi Lemivaa Lalii' sebagai tanda pensucian. Prosesi Lemivaa Tasam bedanya terdapat pembersihan pada benda-benda pusaka yakni Mandau dan sebagainya.

Secara simbolik, prosesi Lemivaa Tasam sebagai bentuk perlindungan agar peserta dalam upacara dapat terlindungi dari ganguan makhluk lain atau terhindar dari hal-hal buruk saat melakukan ritual Hudoq Kawit (dilapangan).

Semua prosesi upacara dilakukan dengan persiapan matang baik penentuan waktu, kelengkapan upacara meliputi; sesaji, peserta upacara, musik Daak Maraaq, Daak Hudoq dan penari Hudoq. Adapun keseluruhan pelaksanaan dari upacara Hudoq sebagai arena simbolik, terdiri dari; (1) Lemivaa Lalii; (2) Hudoq Taharii; (3) Lemivaa Tasam; (4) Hudoq Kawit dan; (5) Hudoq Pakoq. Rangkaian tahapan upacara di atas, memiliki pemaknaan simbolik yang saling terhubung antara kegunaan dan fungsinya. Menurut Edi Sedyawati

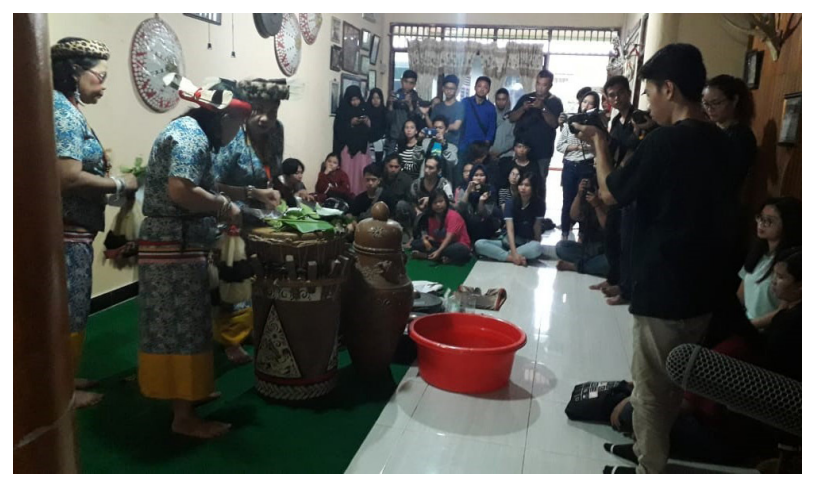

Gambar 1: Suasana prosesi Lemivaa Lalii'. (Foto: Dokumentasi Studi Pengetahuan Musik Nusantara 2019, Kresna Syuhada) aspek kegunaan dan fungsionalnya dapat direlasikan melalui beberapa tahapan yaitu:

“(1) mengundang kekuatan gaib, (2) menjemput roh-roh baik, (3) mendatangkan roh di tempat pemujaan, (4) peringatan pada leluhur, (5) perangkat upacara digunakan saat-saat tertentu dalam putaran waktu (6) perangkat upacara dengan lapisan hidup manusia, (7) manifestasi dari keinginan untuk mengungkapkan keindahan semesta (Sudana, 2015).

Penjelasan di atas, merupakan gambaran dari kompleksitas pelaksanaan upacara Hudoq sebagai arena simbolik. Kompleksitasnya tidak terbatas pada aspek kegunaan saja namun juga dalam perspektif fungsionalnya. Pelaksanaan upacara Hudoq terkait erat pada kepercayaan masyarakat Dayak Bahau sebagai aktifitas budaya. Hubungan tersebut menunjukan masyarakat Dayak Bahau, mengenal pola struktur akan pandangan hidup dan sistem keyakinan dalam menciptakan simbol-simbol yang teratur dan dinamis sebagai arena simbolik. Menurut kepercayaan masyarakat Dayak, Hudoq ini akan menjadi penghubung atas kedatangan dewa yang bertujuan melindungi tanaman dari penyakit hama dan binatang hama, sehingga diharapkan kelak memberikan hasil yang dapat mencukupi kebutuhan pangan masyarakat (Winahyuningsih, 2013). Oleh karena itu, untuk mendukung kelancaran proses upacara, maka segala persiapan upacara termasuk sesaji dan kelengkapan lainnya wajib untuk diadakan. Hal ini bertujuan agar prosesi upacara berjalan lancar tanpa hambatan apapun dan sesuai yang diharapkan. Kelancaran itu juga tidak terlepas dari keterlibatan panitia secara aktif, Dayung, pemusik, penari Hudoq dan peserta lainnya baik yang pasif maupun peserta aktif. Semua itu turut berperan secara simbolik.

\section{Makna Simbolik Musikal Daak Maraaq}

Musik Daak Maraaq sebagai sebuah simbol didasarkan pada kolektivitas yang disepakati oleh kondisi tertentu. Peran simbolik musik Daak Maraaq dalam kolektifitasnya tidak saja sebagai kesenian semata, melainkan ia adalah ekspresi 
simbolik didalamnya terdapat fungsi ritual dan fungsi sosial yang saling terintegrasi. Ekspresi simbolik ini membuktikan musik Daak Maraaq sebagai kesenian masyarakat Bahau memiliki keunikan dan kekhasan jika dihadapkan pada bentuk kebudayaan musik lainnya. Ditegaskan juga, simbol atau tanda dapat diamati sebagai sebuah ekspresi simbolik yang dipercaya manusia sebagai pengkhasan sesuatu yang lain (Fretisari, 2016). Kekhasan ini dianggap sebagai simbol, perannya sangat krusial terhadap kebudayaan, karena simbol menampakan representasi global yang memerlukan dan membutuhkan simbol saat mengungkap dan menangkap sesuatu hal (Agustianto, 2011). Konteks pernyataan dari kata "mengungkap dan menangkap" tidak lain keunikan dan kekhasan adalah simbol itu sendiri.

Pertunjukan musik Daak Maraaq yang sakral meski dimainkan secara monoton (terus menerus) namun dipercaya dapat membangkitkan ruang sakralitas dan bersifat kontemplatif. Lebih lanjut ditegaskan Sepdwiko, bahwa pertunjukkan musik memiliki kualitas sakral, unsur-unsur musik umumnya irama/ritme jika di ulang-ulang maka tabuhan tersebut akan memuat makna tingkatan kesakralannya pada roh leluhur dan menghasilkan kedekatan emosionalnya terhadap leluhur (Sepdwiko, 2016). Kondisi tersebut relevan terhadap musikal Daak Maraaq yang memiliki nuansa monoton namun secara simbolik, justru menguatkan nilai sakralitas dan mistiknya. Disamping itu, sekaligus mengingatkan kita bahwa peranan musik yang digunakan menjadi media ritual dipercayai mampu memanifestasikan dan mempengaruhi kondisi kekuatan manusia yang terhubung oleh alam semesta, sehingga jalinan komunikasi antara manusia, makhluk halus dan roh-roh leluhur dapat terjalin (Irawati, 2014).

Selanjutnya, suatu simbol juga tidak lepas dari sebuah mitos yang melekat pada masyarakat, dan itu memerlukan multi interpretasi untuk memahaminya. Manusia tidak pernah mengamati atau mendapatkan secara langsung, melainkan dengan melalui interpretasi simbol. Peristiwa musik Daak Maraaq hubungannya terhadap mitos telah menunjukkan eksistensinya sebagai arena simbolik. Kondisi itu, dapat dipertahankan agar mitos yang berlaku di masyarakat Bahau selalu memiliki daya kekuatan simbol. Kemudian Dillistone (2002) juga menambahkan bahwa, daya kekuatan simbol terletak didalam sifat dasar sosial kemudian emosi yang menarik masyarakat untuk bertindak melalui ideologi simbol dan bisa dipertahankan (Nur Islami, 2014). Mitos yang berlaku dimasyarakat akan bertahan bilamana diikuti dengan kekuatan simbol. Hal ini sejalan dengan pertunjukan musik Daak Maraaq terkait erat dengan mitos dan upacara, dan hingga kini masih bertahan karena didalamnya terdapat kekuatan simbol.

Musikal Daak Maraaq dan Daak Hudoq dianggap penting dalam menjaga keseimbangan mikrokosmos dan makrokosmos. Hadirnya musik Daak Maraaq dan Daak Hudoq dalam upacara Hudoq adalah bentuk legitimasi terhadap adanya kesadaran mitos yang dipercayai untuk menjaga kehidupan yang seimbang, antara alam makrokosmos (hubungan manusia dengan alam semesta) dan mikrokosmos (manusia dan sifat kemanusiaan yang tak kasat mata) alam gaib. Ke-dua musik tersebut menjadi bertahan dan berlangsung hingga saat ini, dikarenakan adanya kesadaran kolektif terhadap kepercayaan mitos pada masyarakat Bahau. Lewat mitos itu orang bisa turut dan mengikuti bagian pada peristiwaperistiwa sekitarnya, bisa menanggapi daya-daya kekuatan alam. Turut menjadi yang dinamakan partisipasi (Van Peursen et al., 2000). Adapun bentuk partisipasi dilakukan melalui kesadaran kolektif terhadap mitos terkomunikasikan melalui aktivitas upacara dan praktik kesenian. Dengan kata lain, pengalaman terhadap mitos orang-orang

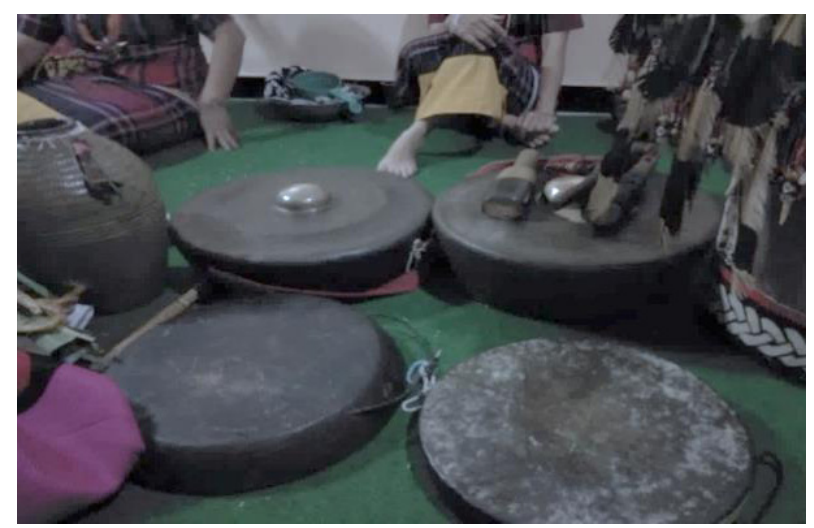

Gambar 2: Prosesi Lemivaa Lalii: penyucian alat musik gong dan mebang. (Dokumentasi oleh: Kresna Syuhada, 2018) 
dapat berbagi suatu sistem sosial spesifik dengan menggunakan banyak pola adat istiadat dan cara hidup, dan menangkap dengan lebih baik nilainilai yang mengikat para anggota komunitas sebagai kelompok utuh (Danesi, 2010).

Fungsi mitos penting untuk melihat bagaimana simbol terwujud karena berbagai aktivitas yang melingkupinya begitu kompleks. Hal ini dapat diamati pada upacara Hudoq melibatkan aktivitas yang kompleks sebagai arena simbolik.

Prosesi Lemivaa Lalii' secara simbolik terdiri dari ucapan doa dari seorang Dayung yang mempercayai adanya kekuatan yang lebih besar dari diri manusia, dan doa menjadi pelindung dari kekuatan negatif atau roh-roh jahat. Situasi tersebut membawa masyarakat Bahau terlibat dalam peristiwa kehidupannya, yang tanggap terhadap daya-daya kekuatan alam sebagaimana tindakan mereka melalui kegiatan upacara adat Hudoq dengan tujuan menghadirkan roh-roh dewa dari langit untuk mencapai kepentingan hidup umat manusia (Asung et al., 2019). Selanjutnya, musikal yang disakralkan dalam upacara Hudoq merupakan bentuk dari representasi simbolik yang membentuk sistem religi dan interaksi dialektis bagi identitas masyarakat Dayak Bahau.

Berdasarkan klasifikasi Victor Turner hubungan makna simbolik musik Daak Maraaq dan Daak Hudoq dalam upacara Hudoq, terdapat tiga tingkatan, dan secara utuh dapat dirumuskan sebagai berikut:

a. Eksegetical meaning

Didapatkan melalui informan, prosesi upacara Hudoq merupakan tradisi bagi masyarakat Dayak Bahau. Praktik upacara tidak lain untuk menciptakan keselarasan dengan lingkungan alam, agar mendapatkan jaminan keberhasilan panen di ladang dengan bantuan oleh dewa (Fauzia, 2013). Menurut pendapat Hadiprayitno (2017:433), semua itu dilakukan karena banyak hal diluar batas kemampuan serta akal manusia, seringkali dituturkan didalam mitos yang menggambarkan betapa besar pengaruh kekuatan diluar dirinya (Pudjasworo et al., 2017). Pendapat tersebut sejalan dengan makna simbolik eksegetical, yang tercermin di dalam setiap prosesi upacara Hudoq, dengan kesadaran adanya bantuan dewa (mikrokosmos). Secara spiritual, masyarakat Bahau menyakini adanya kekuatan selain dari diri manusia dengan memanjatkan doa-doa suci kepada leluhur dan dewa dengan harapan hasil panen terjaga, dan mendatangkan kemakmuran bagi masyarakatnya. Keberhasilan prosesi upacara Hudoq tidak terlepas dengan pendukung lainnya yang disebut sebagai sesaji upacara.

Berdasarkan Eksegetical Meaning, sesaji adalah sarana simbolik untuk menunjukkan rasa hormat terhadap leluhur. Adapun beberapa sesaji yang dihadirkan saat prosesi Lemivaa Lalii' adalah; (1) Beras, yang secara simbolik sebagai ucapan salam kepada roh Hudoq; (2) Air, disimbolkan sebagai lambang kesegaran bagi peserta upacara, memiliki hati yang damai dan bahagia; (3) Kepiting, disimbolkan sebagai pembawa kebaikan dan membuang hal-hal buruk; (4) Daun Uro' Urip, sebagai simbol mudah rejeki; dan (4) Mandau (senjata pusaka) sebagai simbol kekuatan agar tidak lemah. Berbagai jenis sesaji di atas memiliki kandungan makna simbolik dan syarat akan maknanya khususnya sesaji sebagai Eksegetical Meaning.

b. Operational meaning

Upacara Hudoq dalam tingkat makna operasional, adalah kegiatan ritual yang melibatkan mitos-mitos yang sesuai dengan keyakinan masyarakat Bahau. Sebagaimana kita ketahui musik Daak Maraaq secara simbolis merupakan media yang paling disakralkan saat Dayung melakukan prosesi upacara adat Lemivaa Lalii'. Berdasarkan wawancara dikatakan bahwa:

"Yang digunakan tadi tuh ada dua gong dan satu mebang, penamaan musik nya adalah Daak Maraa. Doa yang musik ini disaat ada prosesi ritual pasti dimainkan untuk mengiringi "Maraaq nya para Dayung diucapkan pasti diiringin oleh musik ini, bertujuan supaya suara suara yang diluar yang ibarat mengganggu konsetrasi para Dayung ini tidak terdengar" (Nando, 10 November 2019).

Musik Daak Maraaq yang dimainkan secara konsisten dan polanya monoton, namun secara 
simbolik didalamnya memiliki kekuatan ekspresi dan spritiual. Hal ini sesuai dengan tujuan musik Daak Maraaq yang tidak lain adalah menjadikan upacara menjadi lebih khusyuk dan sakral. Peran musik juga dipercayai untuk menghindari suarasuara yang tidak diinginkan seperti, suara bersin dan suara burung gagak. Suara pantangan sangat dihindari oleh Dayung disaat melakukan prosesi Lemivaa Lalii' karena menandakan adanya kesialan atau petanda buruk yang akan terjadi.

Pengamatan dilapangan, prosesi Hudoq Taharii' dan Hudoq Kawit sebagai Operational Meaning memperlihatkan bagaimana penari Hudoq dilengkapi dengan kostum berhiaskan rumbai daun pisang. Selain peserta menggunakan kostum Hudoq (daun pisang), peserta juga wajib menggunakan topeng Hudoq. Masyarakat suku Dayak di Kalimantan mewarisi topeng Hudoq yang biasanya hadir sebagai seni sakral dalam upacara ritual Hudoq yang memohon kesuburan atau rasa syukur atas panen yang melimpah (Kadek, 2011). Topeng Hudoq sebagai suatu benda yang disakralkan, terlihat ketika masyarakat suku Dayak menyakini adanya keberadaan sosok di luar manusia yang memiliki kekuasaan lebih tinggi dan menjadikan topeng Hudoq sebagai media untuk menampakkan keberadaan mereka melalui manusia (Asung et al., 2019). Jenis topeng Hudoq yang digunakan oleh setiap penari Hudoq, meski terlihat saling berbeda, namun satu sama lainnya tetap estetik dan sakral. Pada umumnya topeng Hudoq yang diukir menyerupai binatang-binatang dimaknai sebagai roh-roh dewa yang menjelma menjadi binatang dengan tujuan dapat mengusir hama yang mengganggu tanaman mereka.

Topeng Hudoq secara simbolik dihadirkan juga sebagai media untuk berkomunikasi dengan para dewa yang bertujuan memberikan kesuburan dan keberkahan hasil tanaman. Menurut Curt Sach (1965) menjelaskan, bentuk-bentuk topeng di atas, merupakan warisan kepercayaan terhadap binatang totem dari kebudayaan lampau yang ada relevansinya dengan totemisme yang banyak terdapat pada zaman Neolith (Hadi, 2006). Penjelasan tersebut menegaskan bagaimana kepercayaan totemisme hingga saat ini masih terjaga dalam kebudayaan masyarakat Dayak Bahau di Kalimantan Timur. Adapun kesakralan dari sebuah topeng Hudoq secara Operational Meaning (makna operasional), dapat ditandai dalam prosesi Hudoq Taharii' dan Hudoq Kawit.

Operational Meaning dari prosesi Hudoq Taharii' secara simbolik ditandai melalui berbagai prosesinya, sebagaimana saat prosesi Napog. Istilah Napoq adalah prosesi penyambutan atas kedatangan Hudoq dengan memegang telur dan mengenakan gelang berwarna putih lalu menuju ke lapangan, dan dilanjutkan dengan prosesi Ngarang Hudoq (menari Hudoq). Saat prosesi Napoq dilangsungkan, iringan musik Daak Maraaq (gong dan mebang) tetap dimainkan dan disertai dengan pembacaan doa oleh Dayung. Setelah seluruh penari Hudoq memasuki lapangan barulah akan dilakukan Ngarang Hudoq (menari Hudoq) disertai musik Daak Hudoq. Kondisi ini menggambarkan perubahan dari musik Daak Maraak berubah menjadi musik Daak Hudoq

Prosesi Ngarang Hudoq dilakukan dengan mengitari lapangan sambil menari bersama dalam suasana suka dan gembira.Ngarang Hudoq bagi masyarakat Dayak Bahau merupakan ekspresi gerak tarian dinamis yang merupakan wujud penghomatan terhadap roh leluhur dan biasanya dilakukan sebagai bagian dari upacara adat (Suprayitno et al., 2018). Iringan musik yang dimainkan saat Ngarang Hudoq menggunakan musik Daak Hudoq dengan semangat suka cita. Hal inti yang dapat dipetik dari konsep pemikiran ini bahwa, eksistensi sebuah tari tidak dapat dilepaskan dengan kehadiran musik yang teratur, terpola, ritmis atau musik yang berirama (Firmansyah et al., 2019). Pendapat tersebut sejalan dimana musik dan tari sebagai satu kesatuan dan keteraturan saat Ngarang Hudoq.

Secara Operational Meaning, ritual Hudoq Taharii' dan Hudoq Kawit menunjukkan adanya hubungan sosial yang berlangsung baik secara individu atau kolektif sebagai interaksi simbolik. Dengan kata lain, individu secara mental tidak hanya membentuk makna dan simbol semata, tetapi ia juga proses pembelajaran atas makna 
dan simbol selama hubungan sosial masih berlangsung (Haris \& Amalia, 2018). Bentuk interaksi sosial ditandai oleh adanya respon fisik melalui proses komunikatif antara penari dengan penonton. Penonton adalah pelaku individu atau kolektif dengan tujuan hadir untuk menyaksikan sebuah pertunjukan seni (Hartitom, 2019). Hubungan interaksi ini sebagai bentuk pengalaman estetis karena peristiwa pertunjukan seni Ngarang Hudoq orang-orang dapat saling berinteraksi secara langsung dengan menari bersama. Penonton yang hadir tidak saja dari kalangan masyarakat dayak Bahau tetapi juga dari masyarakat lainnya. Keyakinan interaksi sosial inilah yang mendasari seni pertunjukan tidak terpisahkan dari unsur yang saling terkait pada latar belakang pengetahuan, sosial budaya, ekonomi, dan kebiasaan masyarakat (Rustim \& Simatupang, 2019).

Hasil interaksi sosial merupakan bentuk dari kontak sosial. Adapun kontak sosial dalam hal ini dapat diterjemahkan ke dalam tiga kategori yakni; (1) kontak sosial yang memungkin setiap orang terjadi kontak antar perorangan, (2) kontak sosial antara perorangan dengan kelompok tertentu, dan (3) kontak sosial kelompok satu dengan kolompok lainnya (Wadiyo, 2006). Dengan demikian, maka interaksi sosial sebagai penguatan makna simbolik terintegrasi secara Operational Meaning yang membuktikan upacara Hudoq sebagai Arena simbolik.

c. Positional meaning

Positional meaning, merupakan interpretasi dalam hubungannya dengan simbol lain. Dalam perspektif ontologis, sebuah simbol menyangkut

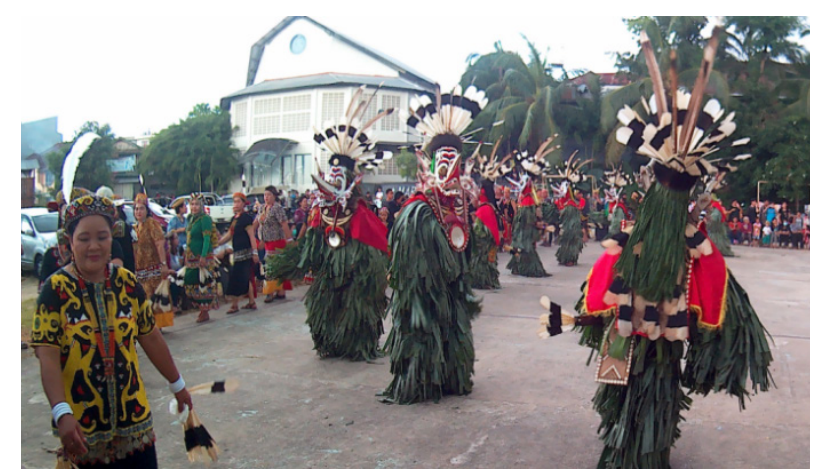

Gambar 3: Suasana prosesi Hudoq Taharii’. (Dokumentasi pribadi: Asril Gunawan, 2014) kehidupan sehari-hari sebagai dimensi horizontal dan dimaknai sebagai keyakinan yang transenden sebagai dimensi vertikal. Keyakinan terhadap transendental adalah bentuk berserah diri kepada Amitinge (tuhan) dan dewa yang diyakini mampu mendatangkan kebaikan. Dalam prosesi ini Dayung membacakan doa keselamatan kepada peserta upacara disertai alunan musik Daak Maraaq dan disajikan bendabenda pusaka dengan tujuan mendapatkan kebaikan dan terhindar dari roh-roh jahat (Agustianto, 2011). Secara simbolik musik Daak Maraaq dalam dimensi horizontal berhubungan dengan manusia dan manusia (makrokosmos). Artinya, musikal Daak Maraaq memberikan sugesti sosial untuk berkumpul bersama dalam suasana sakral khususnya prosesi Lemivaa Lalii' dan Lemivaa Tasam. Suasana sakral dan gembira bercampur aduk saat prosesi Hudoq Taharii' dan Hudoq Kawit yang disertai dengan menari bersama (Ngarang Hudoq). Selanjutnya, dimensi vertikal ditandai dengan prosesi upacara ketika Dayung menyampaikan doa dan harapan kepada Amitinge (tuhan) dan mendatangkan roh roh Dewa atau Leluhur (mikrokosmos). Kondisi tersebut diposisikan berdasarkan konteksnya bahwa masyarakat Bahau di Kalimantan Timur, sangat menjunjung tinggi akan nilai-nilai adat istiadatnya. Oleh sebab itu, setiap perayaan upacara Hudoq selalu ramai dikunjungi dari berbagai eleman masyarakat, seniman, maupun budayawan.

\section{Makna Simbolik Musikal Daak Hudoq}

Musik Daak Hudoq yang disajikan saat prosesi Hudoq Taharii' merupakan musik yang sangat attraktif dan komunikatif. Makna simbolik Daak Hudoq yang bersifat sakral namun sajiannya juga memberikan fungsi hiburan. Ia dikatakan sakral karena secara simbolik digunakan dalam Hudoq Taharii' untuk meminta perlindungan atas keberhasilan perladangan masyarakat Bahau kepada Dewa (mikrokosmos). Begitu juga halnya musik Daak Hudoq adalah peristiwa simbolik, didalamnya terdapat perilaku individu maupun kolektif dalam menciptakan terwujudnya 
simbol-simbol berdasarkan nilai yang melekat di masyarakat Dayak Bahau.

Penyajian musik Daak Hudoq secara musikal sangat sederhana. Hal mendasar untuk diperhatikan bahwa peristiwa musikal selalu melibatkan aspek pendengaran (auditif) bagi manusia (Sumaryanto, 2000). Namun, dibalik aspek pendegaran (auditif) tadi, penyajian musik Daak Hudoq tidaklah mudah. Musik harus dimainkan secara terus menerus dengan saling bergantian dan musik tidak boleh terputus karena sedang mengiringi Ngarang Hudoq (menari Hudoq). Semangat para pemain dalam memainkan musik, secara simbolik adalah bentuk tanggung jawab dalam memainkan perannya. Kondisi itu, serupa bagi semua peserta dalam memainkan setiap perannya, disertai dengan sikap tanggung jawab. Artinya, Kontribusi setiap orang (panitia, seniman, budayawan) diperlukan, walaupun kondisinya bervariasi, semua tergantung pada kemampuan dan perannya masing-masing (Adi \& Ma’arif, 2020). Kondisi yang sama, pemain musik memiliki pengaruh besar dalam menciptakan suasana, selain dimengerti oleh pendengar juga diharapkan menghasilkan alunan musik yang dapat dinikmati (Perdana et al., 2017). Melalui kemampuan pemusik dalam menghasilkan riuh dan ramainya alunan musik yang dimainkan, secara tidak langsung mempengaruhi penari menjadi lebih ekspresif. Penonton yang hadir meyaksikan acara, biasanya spontan ikut menari dengan terlibat langsung ke dalam lingkaran karena terbawa oleh pengaruh alunan musik.

Instrumen musik Daak Hudoq umumnya terdiri dari instrumen gong dan tuvung (perkusi). Jumlah instrumen musik dikondisikan sesuai jumlah instrumen yang ada. Ke-dua instrumen tadi secara karakteristik musikal, dipengaruhi oleh tempo. Alunan dan tempo Daak Hudoq, secara konsisten merepresentasikan identitas, keyakinan dan simbol ekspresi bagi masyarakat Bahau di Samarinda. Musik simbol ekspresi, terlihat ketika alunan dan tempo musik dimainkan, maka penari Hudoq akan merespon secara aktif dengan menari secara estetis dan ekspresif. Sebagai penari sudah menjadi tuntutan terhadap kepekaan, reflektivitas (improvisasi yang terlatih) dalam sikap siaga dan luwes terhadap segala kemungkinan, sebagaimana sikap penari tradisi (Rustiyanti, 2019). Gerakan tarian Hudoq bukanlah hal yang sulit untuk dilakukan karena anak-anak maupun dewasa sebagian besar pandai dalam berimprovisasi. Dalam artian, menari sudah menjadi tradisi bagi kehidupan masyarakat Dayak Bahau.

Selanjutnya, makna simbolik musikal Daak Hudoq sebagai konsep perilaku atau tindakan adalah unsur yang substansial. Tindakan manusia merupakan realitas sosial yang melahirkan tindakan simbolis. Adapun tindakan simbolis dimana irama atau ritmis menjadi pokok utama dalam komposisi musik iringan tari karena pada dasarnya instrumen yang digunakan lebih ditekankan pada alat musik ritmis (Ekasari, 2017). Menurut pandangan Bekker, tindakan manusia dibedakan berdasarkan tingkatan penghayatannya salah satunya adalah, tindakan simbolis sifat komunikasi berjangka lama (dalam Agustianto, 2011).

Musikal Daak Hudoq sebagai tindakan simbolis dapat menjadi sarana komunikasi budaya. Komunikasi budaya tidak lain sebagai ikatan simbolik. Artinya, manusia dalam konteks budaya, sejatinya tidak terpisahkan dengan ikatan simbolik dalam merepresentasikan nilai-nilai kearifan lokalnya. Manusia akan selalu membutuhkan pembinaan dalam menggunakan musikal sebagai representasi makna simbolik. Pembinaan musikal yang baik nantinya dapat memberikan kontribusi terhadap eksistensi dan interaksi seseorang di tengah lingkungannya (Djohan, 2009). Oleh sebab itu, seorang pemain musik Daak Hudoq pastinya memiliki kemampuan musikal yang paham akan lingkungan budaya musiknya.

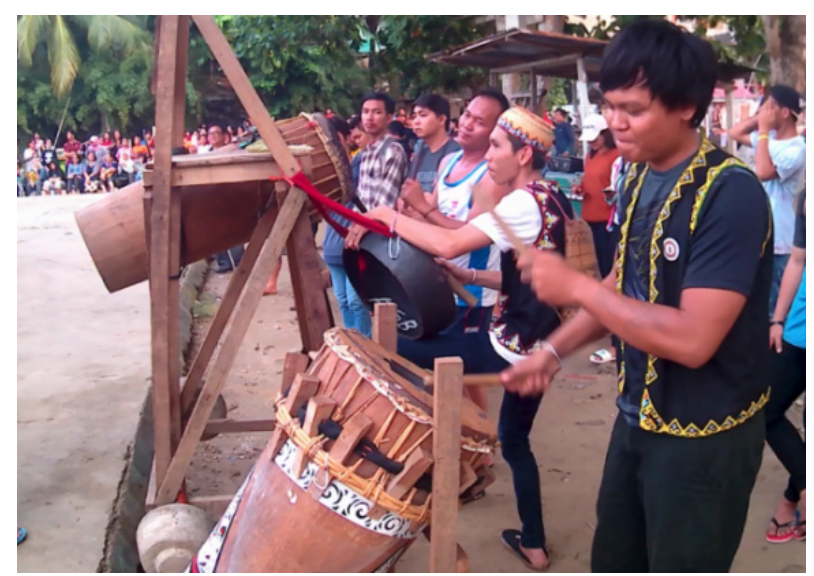

Gambar 4: Penyajian musik Daak Hudoq. (Dokumentasi pribadi: Asril Gunawan, 2014) 


\section{Transkrip Notasi Daak Maraaq dan Daak Hudoq}

a. Notasi Daak Maraaq

Musik Daak Maraaq sebagaimana dijelaskan pada bab sebelumnya, terdiri dari dua jenis instrumen yakni gong (agung) dan Mebang. Berdasarkan transkrip musik (notasi) di atas menunjukkan bahwa pola ritme tabuhan musik Daak Maraaq dimainkan dengan cara saling mengisi antara instrumen gong dan mebang (Interlocking Figurations). Adapun permainan musik Daak Maraaq dimainkan dengan ritme repetisi (pengulangan).

Pola ritme Daak Maraaq menggunakan birama empat perempat (4/4). Angka empat di atas (4/) menunjukkan ada empat ketukan dalam setiap birama dan angka empat (/4) di bawah menunjukkan not seperempat (1/4). Kesatuan bunyi repetisi (pengulangan) yang dihasilkan dari pola ritme tersebut secara simbolik adalah sakral dan bernuansa mistis. Hal ini dapat dianalogikan sebagaimana instrumen perunggu lainnya jika dimainkan secara berulang memiliki aura mistis. Pola ritme sederhana jika didengarkan secara kontinyu akan membawa efek hipnotis, terutama ketika ritme dalam kesyahduan, ritual (Tatubeket et al., 2019). Oleh karena itu musik Daak Maraaq yang dihadirkan dalam prosesi Lemivaa Lalii' secara simbolik sangat relevan dengan sifatnya yang sakral dan mistis.

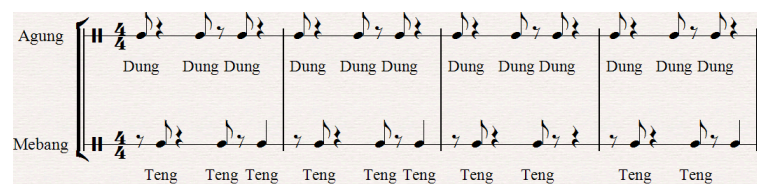

Notasi 1: Pola ritme Daak Maraaq. (Ditranskrip oleh Asril Gunawan)

\section{b. Notasi Daak Hudoq}

Secara karakteristik, bentuk sajian musik Daak Hudoq dengan musik Daak Maraaq sangatlah berbeda. Musik Daak Hudoq memiliki kecendrungan lebih energik dan semangat, sementara musik Daak Maraaq lebih hikmat dan sakral. Penyajian musikal Daak Hudoq dan Daak Maraaq tidak jauh berbeda karena keduanya dimainkan secara berulang-ulang namun tetap menggunakan pola ritme yang berbeda. Ketukan dan aksentuasi irama musik
Daak Hudoq dimainkan dengan teknik Tutti (satu suara) dan tidak menutup kemungkinan dimainkan secara Interlocking Figurations antara instrumen Tuvung (gendang) dan gong. Perbedaan intrumen tersebut Tuvung dan gong dalam pembentukan musikalnya memiliki karakter dan warna suara yang khas. Perbedaan timbre suara sangat ditentukan oleh beberapa hal seperti organologi akustiknya, dan teknik permainan instrumen (Firmansyah et al., 2019). Selanjutnya ditegaskan juga bahwa, kualitas suara yang dikeluarkan tergantung kepada materi atau bahan alat musik itu sendiri (Syeilendra, 2012). Prinsipnya adalah pembuatan dan karakteristik musikal Tuvung dan gong sebenarnya ditentukan pada kebutuhan masyarakat pendukungnya.

Permainan musikal Daak Hudoq sangat dipengaruhi permainan tempo. Tempo adalah kecepatan dalam ukuran langkah tertentu; kecepatan dengan membandingkan gerak atau gerak tari tertentu (Banoe, 2003). Kesan semangat pada musik Daak Hudoq tidak lain digunakan untuk mengiringi tarian Ngarang Hudoq agar semakin hidup.

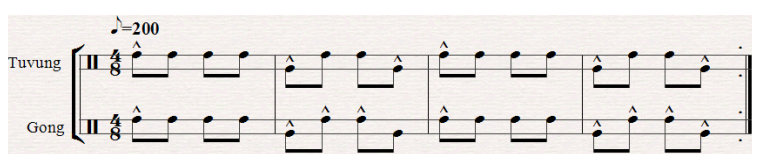

Notasi 2: Pola ritme Daak Hudoq. (Ditranskrip oleh Asril Gunawan)

Berdasarkan transkrip notasi di atas dapat dijelaskan bahwa, pola ritme musik Daak Hudoq menggunakan birama 4/8 (empat per delapan). Angka empat di atas (4/) menunjukkan ada empat ketuk dalam setiap birama dan angka delapan dibawah (/8) menunjukkan nilai not seperdelapan. Secara simbolik pola irama musikal Daak Hudoq yang terkesan energik dan semangat, sebagai bentuk rasa syukur dan harapan hasil panen yang melimpah.

\section{Kesimpulan}

Upacara Hudoq yang diselenggarakan setiap tahunnya oleh masyarakat Bahau di Samarinda, telah menunjukan antusiasme masyarakat berlaku secara kolektif. Sebagai bukti, kesenian tradisi musik Daak Maraaq dan Daak Hudoq mampu 
merepresentasikan makna simbolik yang sejalan dengan tujuan spiritual masyarakat Bahau. Musik Daak Maraaq dan Daak Hudoq hakikatnya terintegrasi ke dalam wujud pemersatu bagi realitas sosial masyarakat Dayak Bahau di Samarinda. Upacara Hudoq adalah rangkaian peristiwa sakral yang bertujuan mendatangkan roh-roh kebaikan agar produktivitas tanaman menjadi meningkat dan mendapatkan hasil yang lebih baik saat panen tiba. Hadirnya musik Daak Maraaq dan Daak Hudoq, juga berperan sebagai sarana komunikasi simbolik dalam dimensi vertikal (manusia dan roh/ dewa) maupun horizontal (manusia dan manusia). Artinya, dalam pelaksanan upacara Hudoq, peran musik secara simbolik menjadi sarana mediasi spiritual, untuk meningkatkan konsentrasi spiritual Dayung saat prosesi upacara berlangsung.

Representasi makna simbolik musikal Daak Maraaq dan Daak Hudoq, semua akan kembali pada kesadaran mitos itu sendiri. Ia akan selalu ada dan terus konsisten bilamana simbol yang ditandai melalui kekuatan mitos selalu terjaga dan terpelihara. Sebaliknya representasi simbol, akan hilang bilamana mitos yang berlaku sudah tidak diyakini lagi akibat bergesernya cara pandang masyarakat dalam menempatkan mitos. Seiring perkembangan zaman, pelaksanaan upacara $H u d o q$ dan kesenian tradisi; musik Daak Maraaq, Daak Hudoq, dan tarian Hudoq sebagai arena simbolik menjadi penting untuk dipertahankan keberlanjutannya.

\section{Kepustakaan}

Adi, B. T. K., \& Ma’arif, S. (2020). Komunitas Lima Gunung: Concept of Art Communitas on Five Slopes Mountain of Central Java, Indonesia. International Journal of Visual and Performing Arts, 2(2), 60-71.

Agustianto, A. (2011). Makna Simbol dalam Kebudayaan Manusia. Jurnal Ilmu Budaya Unilak, 8(1), 1-7.

Asung, D. D., Dahlan, D., \& Purwanti, P. (2019). Religiositas dalam Mitos Upacara Adat Hudoq Dayak Bahau di Ujoh Bilang Kecamatan Long Bagun Kabupaten Mahulu. Jurnal Ilmu Budaya, 3(4), 430-441. https:// doi.org/10.5281/ilmubudaya.v3i4.2178
Banoe, P. (2003). Kamus Musik. Yogyakarta: Kanisius.

Djohan, D. (2009). Kemampuan Musikalitas Sebagai Sarana Pengembangan Keterampilan Sosial. Jurnal Penelitian Dan Evaluasi Pendidikan, 13(1), 111-129.

Ekasari, A. (2017). Karakteristik Musik Iringan Tari Topeng Ireng Di Wonolelo. Pend. Seni Musik-S1, 6(5), 332-341.

Eriksen, T. H. (2009). Antropologi Sosial dan Budaya Sebuah Pengantar, terj. Yosef Maria Florisan. Yogyakarta: Titian Galang Printika.

Fauzia, L. (2013). Tarian dan Topeng Hudoq Kalimantan Timur. Humaniora, 4(1), 712722. https://doi.org/10.21512/humaniora. v4i1.3481

Firmansyah, F., Simatupang, G. R. L. L., Kusmayati, A. M. H., \& Sushartami, W. (2019). Aksiologi Musikal pada Pertunjukan Tari Tradisional Linda dalam Ritual Adat Keagamaan Karia di Daerah Kabupaten Muna Provinsi Sulawesi Tenggara. Resital: Jurnal Seni Pertunjukan (Journal of Performing Arts), 20(3), 132-149.

Fretisari, I. (2016). Makna Simbol Tari Nimang Padi dalam Upacara Adat Naek Dango Masyarakat Dayak Kanayant. RITME, 2(1), 68-77.

Gunawan, A. (2017). Musik Pa’rawana dan Sayyang Pattuddu dalam Prosesi Upacara Khatam Alquran Suku Mandar di Provinsi Sulawesi Barat (sebuah Pendekatan Etnomusikologis). Journal of Culture, Arts, Literature, and Linguistics, 3(2), 109-126. https://doi. org/10.30872/calls.v3i2.877

Hadi, Y. S. (2006). Wayang Topeng dan Cerita Roman Panji dalam Perjalanan Budaya $\bigotimes$ dalam buku Jaringan Makna Tradisi hingga Kontemporer. In M. A. Burhan (Ed.), 1 Februari. BP ISI Yogyakarta.

Hartitom, H. (2019). Rabab Pasisia sebagai Pertunjukan Seni Tutur di Kabupaten Pesisir Selatan. Resital: Jurnal Seni Pertunjukan (Journal of Performing Arts), 20(1), 1-12.

Haryanto, N. (2015). Musik Suku Dayak: Sebuah Catatan Perjalanan di Pedalaman Kalimantan. ISI Yogyakarta.

Heriyawati, Y. (2016). Seni Pertunjukan dan 
Ritual. Yogyakarta : Penerbit Ombak.

Humaeni, A. (2013). Makna Kultural Mitos dalam Budaya Masyarakat Banten. Antropologi Indonesia, 33(3), 159-179. https://doi. org/10.7454/ai.v33i3.2461

Indrawan, A., Gathut Bintarto, A., Rokhani, U., Dona Hapsari, P., Suryati, S., Wahyu Widodo, T., \& Tyasrinestu, F. (2018). Berbagi Musik: Persembahan untuk Sang Maha Guru. BP ISI Yogyakarta.

Irawati, E. (2014). Makna Simbolik Pertunjukan Kelentangan dalam Upacara Belian Sentiu Suku Dayak Benuaq Desa Tanjung Isuy, Kutai Barat, Kalimantan Timur. Jurnal Kajian Seni, 1(1), 60-73. https://doi.org/ doi.org/10.22146/art.5876

Kadek, S. (2011). Topeng Menyingkap Karakter Manusia dan Sejarah Masyarakat. Artikel Bulan Juli (2011), 2(7), 1.

Muthohar, A., \& Masykhur, A. (2020). Islam Dayak: Dialektika Identitas Dayak Tidung dalam relasi Sosial-agama di Kalimantan Timur. Hikmah Journal of Islamic Studies, 11(1), 1-32.

Nur Islami, M. E. (2014). Simbol Dan Makna Ritual Yaqowiyu Di Jatinom Klaten. Media Wisata, 12(2), 102-115.

Perdana, F., Sunarto, S., \& Utomo, U. (2017). Kesenian Rampak Kenthong sebagai Media Ekspresi Estetik Masyarakat Desa Kalirejo Kabupaten Pekalongan. Catharsis, 6(1), 1-8.

Pratiwinindya, R. A., Iswidayati, S., \& Triyanto, T. (2017). Simbol Gendhèng Wayangan pada Atap Rumah Tradisional Kudus dalam Perspektif Kosmologi Jawa-Kudus. Catharsis, 6(1), 19-27. https://doi.org/10.15294/ catharsis. v6i1.17028

Pudjasworo, B., Prasetya, H. B., Wayan Senen, I., HB Raditya, M., Rokhani, U., \& Yudiaryani, Y. (2017). Karya Cipta Seni Pertunjukan. Yogyakarta: JB Publisher.

Rustim, R., \& Simatupang, G. R. L. L. (2019). Interaksi Sosial Tradisi Bagurau Saluang Dendang Minangkabau di Sumatera Barat. Resital: Jurnal Seni Pertunjukan (Journal of Performing Arts), 20(1), 36-51.

Rustiyanti, S. (2019). Metode 'TaTuPa'Tabuh
Tubuh Padusi sebagai Musik Internal Visualisasi Koreografi NeoRandai. Resital: Jurnal Seni Pertunjukan (Journal of Performing Arts), 20(3), 161-175.

Santosa, Aton Rustandi Mulyana, Z. M. (2007). Etnomusikologi Nusantara: Perspektif dan Masa Depannya. ISI Press Surakarta.

Sepdwiko, D. (2016). Hadirnya Musik Gong Perunggu Dalam Upacara Adat Kenduri Sko Pada Masyarakat Kerinci Provinsi Jambi. Jurnal Sitikara, 1(3), 1-14. https://doi.org/ http://dx.doi.org/10.31851/sitakara.v0i0.702 Sudana, I. W. (2015). Eksistensi Rerajahan Sebagai Manifestasi Manunggalnya Seni Dengan Religi. Imaji, 7(2), 141-158. https://doi. org/10.21831/imaji.v7i2.6631

Sumaryanto, F. T. (2000). Kemampuan Musikal (Musical Ability) Dan Pengaruhnya Terhadap Prestasi Belajar Musik. Harmonia Journal of Arts Research and Education, 1(1), 1-8. https:// doi.org/10.15294/harmonia.v1i1.839

Suprayitno, A. M. P. H., Wardani, L. K., \& Frans, S. M. (2018). Implementasi Rumah Lamin Pada Pusat Kesenian Suku Dayak di Kota Samarinda. Intra, 6(2), 325-335.

Syeilendra, S. (2012). Instrumen Musik Talempong Minangkabau dalam Kajian Organologis. Komposisi: Jurnal Pendidikan Bahasa, Sastra, dan Seni, 10(1), 54-59. https://doi. org/10.24036/komposisi.v10i1.56

Tatubeket, R. M., Agustina, A., \& Ef, A. (2019). Peran Musik Tuddukat Dalam Ritual Arat Sabulungan Di Kabupaten Mentawai. Jurnal Sosiologi Agama, 13(1), 75-105.

Wadiyo. (2006). Seni sebagai Sarana Interaksi Sosial (Art as a Tool of Social Interactions). Harmonia: Jurnal Pengetahuan Dan Pemikiran Seni, 7(2), 1-9. https://doi.org/10.15294/ harmonia.v7i2.771

Winahyuningsih, M. H. (2013). Tatag De Penyawo: Perenungan Atas Identitas Kesukuan. Resital: Jurnal Seni Pertunjukan, 14(1), 9-23. https:// doi.org/10.24821/resital.v14i1.391

Yanti, N. H. (2019). Makna Simbolik Topeng Tarian Hudoq Pada Upacara Panen Masyarakat Suku Dayak. Imaji: Jurnal Seni dan Pendidikan Seni, 17(1), 13-26. 